\title{
FAKTORYANG MEMPENGARUHI KEPUTUSAN KONSUMEN DALAM MEMILIH AIR MINUM KEMASAN "HK" DI DESA CENLECEN KECAMATAN PAKONG KABUPATEN PAMEKASAN
}

\author{
Mohammad Herman Djaja \\ Ria Marisa
}

Universitas Madura

\begin{abstract}
ABSTRAK
Latar belakang masalah dari penelitian ini adalah : Seiring dengan sejarah manusia dalam memenuhi kebutuhannya, ada pihak yang meminta dan ada pihak yang menawarkan. Pemasaran banyak menarik perhatian yang sangat besar baik dari perusahaan yang berskala internasional, nasional, maupun regional.Salah satunya produk yang menjadi kebutuhan manusia dalam sehariannya yaitu air minum dalam kemasan.

Tujuan penelitian ini adalah : Permata untuk mengetahui pengaruh faktor marketing mix yang terdiri dari faktor produk, harga, promosi dan tempat secara bersamaan terhadap keputusan konsumen dalam memilih air minum kemasan "HK"di desa cenlecen kecamatan pakong kabupaten pamekasan. Serta ingin mengetahui faktor yang paling dominan dari keempat faktor tersebut.

Pengumpulan data pada penelitian ini adalah : dengan mengedarkan angket atau kuesioner, sebanyak 60 angket kepada responden. Dari Uji Validitas sebanyak 21 Item dinyatakan semualnya valid.Persamaan linier regresi berganda di hitung dengan metode SPSS 21

Dari persamaan nampak bahwa jika tanpa adanya faktor produk, harga, promosi dan tempat tersebut di atas : keputusan konsumen memilih air minum kemasan "HK" di desa cenlecen kecamatan pakong kabupaten pamekasan sebesar $1,575 \%$.

Pada hipotesis pertama : dengan uji $F$ : $F$ hitung sebesar 20,041 lebih besar dari $F$ tabel sebesar 2,53 dan tingkat signifikasi 0,000 masih lebih kecil dari batas signifikasi hipotesis 0,05. Maka hipotesis pertama tersebut, benar dugaan ada pengaruh faktor marketing mix yang terdiri dari faktor produk, harga, promosi dan tempat secara bersamaan terhadap keputusan konsumen dalam memilih air minum HK di desa cenlecen kecamatan pakong kabupaten pamekasan. Faktor yang paling dominan adalah faktor promosi yakni sebesar $57,30 \%$.
\end{abstract}




\section{Keyword : Produk, Harga, Promosi dan Tempat}

\section{PENDAHULUAN}

\subsection{Latar Belakang}

Sektor industri merupakan salah satu penunjang berhasilnya pembangunan ekonomi, dengan demikian tidaklah mengherankan apabila semakin banyak perusahaan berdiri, sekalipun perusahaanperusahaan tersebut belum bisa dipastikan berhasil sesuai dengan yang diharapkan tanpa ditunjang dengan pengelolaan manajemen yang baik. Ditengah berkembangnya persaingan dalam dunia usaha yang berorientasi pada laba dari saat ini, dari sekian banyak perusahaan yang menggeluti dunia produksi yang bersifat konsumtif, tak jarang ada usaha keras dari masing-masing perusahaan untuk mempertahankan konsumen dan bahkan berusaha untuk memperoleh konsumen baru agar bisa mempunyai daya tarik, mempunyai minat, dan keputusan terhadap produknya.

Seiring dengan sejarah manusia dalam memenuhi kebutuhannya, ada pihak yang meminta dan ada pihak yang menawarkan. Pemasaran banyak menarik perhatian yang sangat besar baik dari perusahaan yang berskala internasional, nasional, maupun regional. Salah satunya produk yang menjadi kebutuhan manusia dalam kesehariannya yaitu air minum dalam kemasan.

Pada masa sekarang ini banyak sekali beredar produk air minum dengankualitas dan kemasannya. Oleh karena itu persainganpun tidak dapat dihindari lagi, sehingga memacu para pengusaha yang bergerak dibidang tersebut melakukan strategi baru untuk meningkatkan penjualan produknya yang diharapkan akan dapat membantu dalam meningkatkan keputusan konsumen yang pada akhirnya akan mempunyai efek positif terhadap penjualan pada perusahaan tersebut.

Berkembangnya

pengetahuan, tekhnologi dan informasi tidak menutup kemungkinan untuk para pengusaha regional setempat memulai dalam bisnis ini. Salah satunya yakni dengan mendirikan usaha Air Minum Dalam Kemasan HK yang terletak Di Desa Cenlecen Kecamata Pakong Kabupaten Pamekasan. Bermula dari kebutuhan masyarakat yang semakin besar akan konsumsi air minum dalam kemasan maka CV. Tiara Abadi Pamekasan-Indonesia mencoba untuk memproduksi air dalam kemasan dan mendirikan sebuah lebel Air Minum Dalam Kemasan HK untuk memenuhi sebagian besar kebutuhan masyarakat sekitar.

Meskipun pada kenyataannya air di Madura khususnya di Pamekasan banyak mengandung zat kapur yang sangat sulit dipisahkan untuk dijadikan air bersih, layak dikemas dan bahkan layak untuk dikonsumsi. Namun berdasarkan penelitian dan uji coba secara klinis ternyata setelah dilakukan penyulingan hasilnya hampir sama dengan air mineral yang beredar di Pamekasan. Oleh karena itu dengan berbekal keterampilan dan sumber daya manusia yang ada CV. Tiara Abadi Pamekasan-Indonesia berinisiatif untuk mendirikan dan mengembangkan usaha tersebut yang kemudian diberi nama air minum dalam kemasan HK.

Sejak berlakunya persaingan bebas pada era globalisasi 
perusahaan bukan hanya dituntut untuk bertindak efisien dan efektif untuk mencapai laba yang maksimal. Namun perusahaan harus mampu mengelolah tentang faktorfaktor marketing mix yang merupakan inti dari kegiatan pemasaran yang disebut dengan $4 \mathrm{P}$ yakni; faktor produk, harga, promosi dan tempat pada.

Mengembangkan produkdalam dunia usaha tidaklah semudah membalikkan telapak tangan, perlu adanya usaha-usaha yang bersifat kontinu dari pihak pengusaha itu sendiri, utamaya dalam menjaga kualitas produk, penetapan harga yang dilakukan oleh perusahaan tersebut, agar konsumen mempunyai daya tarik terhadap produk tersebut. Oleh karena itu, dalam sebuah produk suatu barang merupakan hal yang perlu mendapatkan perhatian untuk menarik minat terhadap keputusan konsumen, yang dimaksud adalah kemasan, kualitas, merek serta harga.

Berdasarkanuraian tersebut, maka peneliti menetapkan judul penelitian:"Faktor Yang Mempengaruhi Keputusan Konsumen Dalam Memilih AirMinum Kemasan "HK"Di Desa Cenlecen Kecamatan Pakong Kabupaten Pamekasan".

\subsection{Batasan Masalah}

Untuk memperjelas pokok masalah dan membatasi pada pembahasan pemasaran pada khususnya, maka penelitian membatasi pada :

1. Faktor produk, harga, promosi, dan faktor tempat merupakan faktor yang dapat mempengaruhi konsumen membeli air minum kemasan HK Di desa Cenlecen Kecamatan Pakong Kabupaten Pamekasan
2. Responden penelitian adalah konsumen yang pernah dan atau sedang membeli air minum kemasan HK Di Desa Cenlecen Kecamatan Pakong Kabupaten Pamekasan.

\subsection{Tujuan Penelitian}

Berdasarkan

rumusan

masalah yang telah diuraikan di atas dapat ditetapkan bahwa tujuan dari penelitian ini adalah:

1. Untuk mengetahui faktor marketing mix yang terdiri dari faktor produk, harga, promosi, dan tempat secara bersamasama terhadap keputusan konsumen dalam memilih air minum kemasan HK Di Desa Cenlecen Kecamatan Pakong Kabupaten Pamekasan.

2. Untuk mengetahui faktor yang paling dominan terhadap keputusan konsumen dalam memilih air minum kemasan HK Di Desa Cenlecen Kecamatan Pakong Kabupaten Pamekasan.

\subsection{Manfaat Penelitian}

Berdasarkan tujuan penelitian di atas, maka manfaat yang diharapkan dari penulis adalah sebagai berikut :

1. Bagi Perusahaan

Sebagai salah satu sumber informasi bagi perusahaan yang nantinya dapat bermanfaat dalam membantu evaluasi pemasaran produk air minum dalam kemasan HK dan sebagai sarana pengenalan perilaku konsumen melalui fakta psikologis sosial.

2. Bagi Peneliti

Sebagai sarana untuk menambah wawasan penelitian di dalam memecahkan masalah yang berhubungan dengan kajian yang telah dilakukan. Dan memberikan pemahaman mengenai hubungan antara teori dengan pemasalahan yang nyata di lapangan. 
3. Bagi Peneliti Lanjutan

Sebagai bahan informasi kajian ilmu pengetahuan, yang dapat dijadikan acuan pengembangan keilmuan yang berkaitan dengan penelitian.

\subsection{Kerangka Pemikiran}

\section{Gambar 1.1}

\section{Faktor Produk, Harga, Promosi, Tempat Terhadap Keputusan Konsumen Dalam Memilih Air Minum Kemasan "HK" Di Desa Cenlecen Kecamatan Pakong Kabupaten Pamekasan}

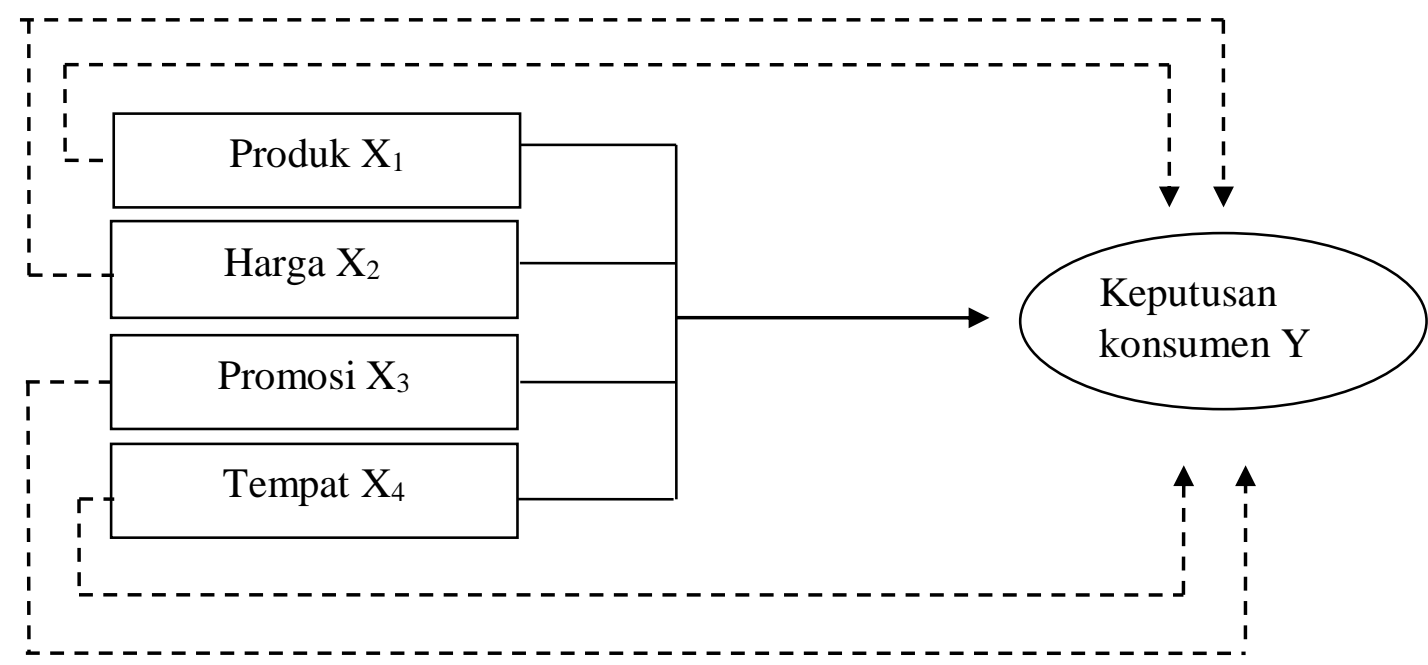

Keterangan :

$r=$ Koefisien korelasi secara parsial pada keempat faktor Marketing Mix yang terdiri dari : faktor produk, harga, promosi, dan faktor tempat.

$r \quad$ adalah untuk mengukur besarnya hubungan pada faktor produk terhadap faktor konsumen membeli yang di ukur dengan, macam atau ragamnya produk, warna, kehandalan, dan kepuasan konsumen.

$r_{2}$ adalah untuk mengukur besarnya hubungan pada faktor harga terhadap faktor konsumen membeli yang di ukur dengan, harga produk, variasi harga, cara pembayaran, dan perbandingan harga dengan perusahaan air minum lainnya.

$\mathrm{r}_{3}$ adalah untuk mengukur besarnya hubungan pada faktor promosi terhadap faktor konsumen membeli yang di ukur dengan, tentang promosi yang dilakukan perusahaan, kepercayaan konsumen dengan promosi, promosi yang dapat menarik konsumen, kesan promosi yang dilakukan perusahaan. $R$

$r_{4}$ adalah untuk mengukur besarnya hubungan pada faktor tempat terhadap faktor konsumen membeli yang di ukur dengan, tempat untuk usahanya, suwasana tempat untuk usaha pelayanan, tempat usaha yang setrategis dengan pemukiman penduduk, manfaat tempat usaha pada masyarakat sekitar.

$\mathrm{R}=$ Koefisien korelasi secara bersama-sama yakni mengukur besarnya hubungan secara bersama-sama / simultan dari keempat faktor marketing mix tersebut di atas. 
KAJIAN PUSTAKA

\subsection{Pemasaran}

Menurut pendapat Kotler

dalam Darmawan (2007:2)

pemasaran adalah proses sosial yang didalamnya adalah individu dan kelompok mendapatkan apa yang mereka butuhkan dan diinginkan dengan menciptakan, menawarkan, dan secara bebas mempertukarkan produk yang bernilai dengan pihak lain.

Pendapat Kotler dalan

Swasta dan Handoko (2000:3-4) pemasaran adalah suatu sistem keseluruhan dan kegiatan-kegiatan usaha yang ditujukan untuk merencanakan, menentukan harga, mempromosikan dan mendistribusikan barang dan jasa yang dapat memuaskan kebutuhan baik kepala pembeli yang ada maupun pembeli yang potensial.

Menurut pendapat American Marketing Association(AMA) dalam Darmawan (2009:2) pemasaran adalah proses perencanaan dan pelaksanaan rancangan, penetapan harga, promosi. Dan distribusi gagasan, barang, dan jasa untuk menciptakan pertukaran yang memenuhi sasaran-sasaran individu dan organisasi.

Stanton dalam Angipora (2002:4) pemasaran adalah sebuah system dan kegiatan bisnis yang dirancang untuk merencanakan memberi harga. Mempromosikan dan mendistribusikan jasa serta barang-barang pemuas keinginan pasar.

Dari definisi tersebut di atas dapat disimpulkan bahwa, dalam pemasaran adalah terpenuhinya kebutuhan dan keinginan dan konsumen, karena yang menjadi sasaran dalam konsumen adalah mempromosikan suatu produk atau jasa, jadi bukan hanya sekedar menjual produk atau jasa melainkan segala aktifitas memperlancar arus barang atau jasa dan produsen ke konsumen sehingga dapat memuaskan kebutuhan dan keinginan konsumen.

Pada dasarnya kegiatan pemasaran harus berorientasi terhadap terciptanya dan pemeliharaan hubungan pertukaran yang memuaskan semua pihak. Pemahaman tentang kegiatan pemasaran memungkinkan untuk mempertimbangkan setiap biaya yang terjadi, menilai setiap keunggulan dan kelemahan bisnis secara efektif, serta bagaimana sasaran untuk kemudian dikembangkan sesuai kondisi yang dialami.

\subsection{Bauran Pemasaran (Marketing Mix)}

Bauran pemasaran adalah perangkat variabel-variabel pemasaran terkontrol yang digabungkan perusahaan untuk menghasilkan tanggapan yang diinginkan dalam pasar sasaran, (target market). Konsep marketing mixmeruapakan segala usaha yang dapat perusahaan lakukan untuk mmepengaruhi permintaan akan produknya (Abgipora, 2002:24).

Menurut Angipora (2002:26-28) unsur-unsur yang terkait dalam bauran pemasaran adalah sebagai berikut :

\section{Produk (Product)}

Meruapakan kombinasi barang dan jasa yang ditawarkan oleh seorang atau lembaga untuk memenuhi kebutuhan dan keinginan pasar. Keberadaan produk dapat dikatakan sebagai titik sentral dan kegiatan marketing, karena semua kegiatan dan unsur-unsur marketing mix lainnya berawal dan berpatokan pada produk yang dihasilkan. Pengenalan secara mendalam suatu produk yang dihasilkan dapat dilihat 
dalam bauran produk (product mix)yang unsur-unsurnya terdiri dari : keanekaragaman atau macammacam produk, kualitas, desain, ciriciri bentuk produk, merk dagang, kemasan, ukuran, pelayanan, jaminan/garansi dan pengembalian.

\section{Harga (Price)}

Merupakan jumlah uang yang harus dibayarkan konsumen untuk mendapatkan suatu produk guna memenuhi kebutuhan dan keinginan yang belum terpuaskan.Di dalam menentukan kebijakan harga dan suatu produk yang dihasilkan tentunya perlu memperhatikan dan secara seksama unsur-unsur yang berkaitan dengan bauran harga (price mix) yang terdiri dan : daftar harga, rabat, potongan tunia, jangka pembayaran, dan syarat kredit. Penetapan unsur-unsur dalam bauran harga dan suatu produk yang dihasilkan merupakan salah usaha dan produsen untuk menarik para konsumen agar mau membeli dalam jumlah yang lebih banyak dan mengikat untuk mmebeli secara kontinyu. Disamping unsur-unsur bauran harga di atas maka di dalam penetapan harga perusahaan juga harus memperhatikan nilai dan manfaat dan produk yang dihasilkan guna memenuhi kebutuhan dan keinginan konsumen.

\section{Promosi (Promotion)}

Merupakan berbagai kegiatan yang dilakukan perusahaan dengan tujuan utama untuk menginformasikan, membujuk, mempengaruhi dan mengingkatkan konsumen untuk membeli produk yang dihasilkan.

Untuk melaksanakan kegiatan promosi produk pemisahaan keseluruhan khususnya kegiatan penjualan, maka produsen harus memilih dan menetapkan secara seksama elemen-elemen dalam bauran promosi (promotion mix)yang terdiri dan perikianan (advertising), penjualan personal (pesonal selling), promosi penjualan (salespromotion), dan publisitas (publicity).

Dengan memperhatikan unsurunsur yang terkait dalam bauran distribusi di atas, maka melalui kegiatan distribusi terhadap produkproduk yang dihasilkan, produsen mengharapkan bahwa, melalui aktivitas tersebut produsen mampu :

a. Menciptakan nilai tambah produk salah satu fungsi pemasaran yang mampu melaksanakan kegunaan bentuk, waktu, tempat dan pemilikan.

b. Memperlancar arus saluran distribusi fisik dan non fisik yaitu aliran kegiatan yang terjadi antara lembaga-lembaga saluran yang terlibat di dalam proses pemasran.

\subsection{Pengertian Promosi}

Menurut Tjiptono (1997:219) promosi merupakan salah satu faktor penentu keberhasilan suatu program pemasaran. Berapapun berkualitasnya suatu produk, bila konsumen belum perlu mendengarnya dan tidak yakin bahwa produk itu akan berguna bagi mereka, maka meraka tidak akan perna membelinya.

Menurut Angiora (2002:374) promosi merupakan cara berkomunikasi yang dilakukan oleh perusahaan untuk mendorong atau menarik calon konsumen agar membeli produk atau jasa yang ditawarkan. Karena promosi itu sendiri merupakan suatu alat yang dipakai untuk menginformasikan, mempengaruhi dan mengingatkan kepada konsumen akan produk yang ditawarkan perusahaan.

\subsection{Tujuan Promosi}

Tujuan utama dan promosi adalah menginformasikan, 
mempengaruhi dan membujuk serta mengingatkan pelanggan sasaran tentang perusahaan dan bauran pemasarannya (Tjiptono, 1997:221222)

Secara rinci ketiga tujuan promosi tersebut dapat dijabarkan sebagai berikut:

\section{Menginformasikan (informing)}

a. Menginformasikan pasar mengenai keberadaan suatu produk baru

b. Memperkenalkan cara pemakaian yang baru dari suatu produk

c. Menyampaikan perubahan harga kepada pasar

d. Menjelaskan cara kerja suatu produk

e. Menginformasikan jasa-jasa yang disediakan oleh perusahaan

f. Meluruskan kesan yang keliru

g. Mengurangi ketakutan atau kekhawatiran pembeli

h. Membangun citra perusahaan

\section{Membujuk pelanggan sasaran (persuading)}

a. Membentuk pilihan merek

b. Mengalihkan pilihan ke merek tertentu

c. Mengubah persepsi pelanggan terhadap atribut produk

d. Mendorong pembeli untuk belanja saat itu juga

e. Mendorong pembeli untuk menerima kunjungan wiraniaga (salesman)

\section{Mengingatkan (reminding)}

a. Mengingatkan pembeli bahwa produk yang bersangkutan dibutuhkan dalam waktu dekat

b. Mengingatkan pembeli akan tempat-tempat yang djual produk perusahaan

c. Membuat pembeli tetap ingat walaupun tidak ada kampaye iklan d. Menjaga agar ingatan pertama pembeli jatuh pada produk perusahaan.

\subsection{Keuntungan Promosi}

Apabila promosi dapat dilaksanakan dengan baik oleh perusahaan maka akan memperoleh keuntungan-keuntungan diantaranya

a. Penghematan biaya

Dengan mengadakan kegiatan promosi maka perusahaan akan dapat menjangkau sasaran dan jumlah yang banyak, hal ini karena jangkauan promosi adalah luas, sehingga dengan demikian perusahaan akan dapat menghemat biaya yang dikeluarkan.

b. Dapat mencapai sasaran yang dimaksud

Apabila perusahaan memilih sasaran yang akan dituju adalah pasar lokal maka media yang dipergunakan adalah surat kabar lokal, sehingga dalam pencapaian sasaran yang dituju akan mudah tercapai.

c. Dapat selalu diingat

Dengan mengadakan promosi maka produk akan selalu diingat oleh konsumen, hal ini dikarenakan permanennya tulisan dan gambar yang setiap saat bisa diingat oleh masyarakat.

Dengan keuntunga-keuntungan yang dimiliki oleh perusahaan apabila menggunakan promosi maka usaha perusahaan dalam memperkenalkan atau menawarkan produknya akan lebih berhasil dibandingkan dengan perusahaan yang tidak menggunakan promosi dalam usaha mencapai tujuan perusahaan.

\subsection{Bauran Promosi(Promotion mix)}

Secara umum bentuk-bentuk promosi memiliki fungsi yang sama, 
tetapi bentuk-bentuk tersebut dapat dibedakan berdasarkan tugas-tugas khususnya.

Beberapa tugas khusus itu sering bauran promosi (promotion mix). Menurut Angipora (2002:344) meliputi antara lain :

\section{Periklanan (Advertising)}

Alat promosi yang paling luas digunakan adalah periklanan. Periklanan dilakukan sebagai upaya untuk mengkomunikasikan produk perusahaan guna mempengaruhi perilaku konsumsi para konsumennya. Pengertian periklanan sendiri oleh Basu Swasta dalam Angipora (2002:344) adalah sebagai berikut" periklanan adalah komunikasi non individu, dengan sejumlah biaya, melalui berbagai media yang dilakukan oleh perusahaan, lembaga, non lembaga, non laba, serta individu-individu.

\section{Penjualan Personal (Personal Selling)}

Penjualan personal dikatakan sebagai alat promosi yang paling efektif karena perananya yang besar dalam menciptakan dan memelihara hubungan komunikasi yang dinamis dan fleksibel diantara pihak-pihak yang melakukan pertukaran.Dikatakan dinamis dan fleksibel karena dalam komunikasi penjualan ini memungkinkan semua pihak lainnya. Penjualan personal adalah interaksi antar individu, saling bertemu muka yang ditujukan untuk menciptakan, mmeperbaiki, menguasai, atau mempertahankan hubungan pertukaran yang saling menguntungkan dengan pihak lain, menurut Swasta dalam (Angipora, 2002:366). Penjualan personal meruapakan suatu penyajian secara lisan dan tatap muka dihadapan satu calon pembeli atau lebih dengan tujuan untuk menjual suatu produk.
Perbedaan antara iklan dengan penjualan personal (personal selling) adalah percakapan dalam iklan bersifat searah dan sepihak sedangkan percakapan dalam penjualan personal bersifat dua arah timbal balik dalam menghadapi calon pembeli.

Penjualan personal mempunyai karakteristik yang sangat berbeda dengan alat promosi yang lainnya. Perbedaan karakteristik itu menyebabkan penjualan personal mempunyai keunggulan-keunggulan tertentu dibandingkan dengan alat promosi lainnya, keunggulan yang menonjol adalah penjualan personal melibatkan komunikasi langsung dengan konsumen potensial (face to face). Pesan penjualan personal sering lebih bisa membujuk dan pada periklanan atau publikasi di media massa. Selain itu proses komunikasi face to face menjadikan konsumen potensial harus memperhatikan pesan yang disampaikan oleh petugas penjual.

\section{Promosi Penjualan (Sales Promotion)}

Untuk menarik konsumen agar segera melakukan pembelian produk baru atau agar lebih banyak mempertimbangkan produk yang telah ada maka perusahaan biasanya menggunakan sarana promosi yang dikenal dengan promosi penjualan (sales promotion).

Promosi penjualan adalah bentuk persuasi langsung melalui pengguna sebagai insentif yang dapat di atur untuk merangsang pembelian produk dengan segera dan meningkatkan jumlah produk yang di beli pelanggan ( Tjipton, 1997:222). Diterangkan di atas bahwa penjualan merupakan insentif yang diberikan baik kepada tenaga penjualan, perantara, maupun konsumen akhir, dan insentif ini bisa 
mengambil berbagai bentuk seperti : paket harga, voucer, hadiah, undian dan discount.

\section{Publisitas (Publicity)}

Publisitas merupakan pelengkap yang efektif bagi alat promosi yang lain seperti periklanan, penjualan personal dan promosi penjualan. Publisitas adalah sejumlah informasi tentang seorang, barang atau organisasi yang di sebarluaskan kepada masyarakat melalui media tanpa di pungut biaya atau tanpa pengawas dan sponsor, menurut Swasta dalam Angipora, (2002:372).

\subsection{Keputusan \\ Konsumen}

pembelian

Pembelian suatu produk merupakan suatu proses dari seluruh tahapan dalam proses pembelian konsumen. Keputusan konsumen ditentukan berdasarkan persepsi konsumen tentang produk tersebut. Suatu tindakan yang terlibat dalam mendapatkan, mengkonsumsi, dan menghabiskan produk dan jasa, termasuk alasan dan keputusan sebelum dan sesudah mengkonsumsi.

\subsection{Struktur Keputusan pembelian / Konsumen \\ Keputusan yang diambil oleh} konsumen itu sebenarnya merupakan kumpulan dan sejumlah keputusan. Hal itu sangat berpengaruh terhadap keputusan pembelian tersebut. Dimana konsumen akan memiliki dan berbagai alternatif pembelian mempunyai struktur komponen adalah sebagai berikut Swastha dan Handoko ( 2000:102-104):

a. Keputusan tentang jenis produk

Konsumen dapat mengambil keputusan untuk membeli sebuah produk atau menggunakan uangnya untuk tujuan lain. b. Keputusan tentang bentuk produk Konsumen dapat mengambil keputusan untuk membeli bentuk produk tertentu keputusan tersebut menyangkut pola ukuran, mutu, corak dan sebagainya.

c. Keputusan tentang merek Konsumen harus menganbil keputusan tentang merek yang mana akan dibeli.

d. Keputusan tentang penjualan Konsumen harus mengambil keputusan dimana produk akan dibeli, apakah pada toko atau pasar tertentu.

e. Keputusan tentang jumlah produk Konsumen dapat mengambil keputusan tentang beberapa banyak produk yang akan dibelinya pada suatu saat.

f. Keputusan tentang waktu pembelian

Konsumen dapat mengambil keputusan kapan ia harus melakukan pembelian.

g. Keputusan tentang cara Konsumen harus mengambil keputusan tentang metode atau pembayaran produk yang dibeli, apakah secara tunai atau secara kredit.

Dalam suatu pembelian barang, keputusan yang diambil tidak selalu berurutan seperti dimuka. Pada situasi pembelian seperti penyelesaian masalah ekstensi, Model yang diambil dapat bermula dan keputusan tentang penjual karena penjual dapat membantu merumuskan perbedaan bentuk, merek, harga dan produk.

\subsection{Proses \\ Keputusan}

Pengambilan

Dalam bentuk pembelian barang, konsumen sering ada lebih dari dua pihak yang terlibat dalam 
proses pertukaran atau pembeliannya. Umumnya ada lima peranan yang dapat dilakukan seseorang. Pemahaman mengenai masing-masing peranan ini sangat berguna dalam rangka memuaskan kebutuhan dan keinginan konsumen, Kotler dalam Teguh (2000:54).

Dari kelima peranan tersebut meliputi :

a. Pemekarsa (Inisiator) adalah orang yang pertama kali menyadari adanya keinginan atau kebutuhan yang belum terpenuhi dan mengusulkan ide untuk membeli.

b. Pemberi pengaruh (Influencer) adalah orang yang akan mempengaruhi keputusan pembelian.

c. Pengambilan keputusan (Desider) adalah orang yang menentukan keputusan pembelian.

d. Pembeli (Buyer) adalah orang yang melakukan pembelian.

e. Pembeli (User)adalah orang yang mengkonsumsi atau menggunakan barang atau jasa yang dibeli

Pada dasarnya pengambilan
keputusan yang dilakukan
konsumen untuk melakukan
pembelian diawali oleh adanya
kesadaran pemenuhan kebutuhan
atau keinginan konsumen itu
senderi. Atas kesadaran pemenuhan
kebutuhan atau keinginan itu, maka
konsumen mulai mencari informasi
tentang produk yang dapat
memenuhi kebutuhan atau
keinginannya. Dan informasi yang
didapat selanjutnya konsumen akan
melakukan seleksi prodak untuk
memilih.

\section{Hipotesa}

Hipotesa penelitian ini sebagai berikut :

1. Diduga ada pengaruh faktor marketing mix yang terdiri dari faktor produk, harga, promosi, dan tempat secara bersamaan terhadap keputusan konsumen dalam memilih air minum kemasan "HK" Di Desa Cenlecen Kecamatan Pakong Kabupaten Pamekasan?

2. Diduga faktor promosi yang paling dominan terhadap keputusan konsumen dalam memilih air minum kemasan "HK" Di Desa Cenlecen Kecamatan Pakong Kabupaten Pamekasan?

\section{METODELOGI PENELITIAN}

\subsection{Lokasi Penelitian}

Lokasi penelitian ini dilakukan di Desa Cenlecen Kecamatan Pakong Kabupaten Pamekasan.

\subsection{Jenis Data dan Sumber Data}

Jenis data yang digunakan pada penelitian ini adalah menggunakan data kualitatif bersekala ordinal.

\subsection{Populasi dan Sampel}

\subsubsection{Populasi}

Yang menjadi populasi pada penelitian ini adalah : semua orang atau masyarakat yang pernah dan atau sedang membeli air minum HK Di Desa Cenlencen Kecamatan Pakong Kabupaten Pamekasan.

\subsubsection{Sampel}

Yang menjadi sampel pada penelitian ini adalah : sebagian konsumen atau masyarakat yang sedang dan atau pernah membeli air minum kemasan $\mathrm{HK}$ Di Desa Cenlecen Kecamatan Pakong Kabupaten Pamekasan. Dengan batasan jadwal waktu pengambilan sampel selama 15hari, diharapkan dapat memperoleh jawaban angket dari responden 60 angket yang di sebar Di Desa Cenlecen. Teknik pengambilan sampelnya pada penelitian ini adalah dengan teknik Sampling Aksidental. 


\subsection{Teknik Pengumpulan Data}

Adapun teknik pengumpulan data pada penelitian ini adalah sebagai berikut :

1. Survey pendahuluan, berupa penelitian secara umum terhadap masyarakat mengetahui permasalahan yang dihadapi.

2. Penelitian lapangan, sebagai suatu upaya dengan melakukan survey terhadap yang akan diteliti untuk memperoleh data primer secara langsung melalui :

a. Wawancara

Tehnik ini dilakukan dengan cara melakukan tanya-jawab secara langsung kepada responden. Hal ini dilakukan untuk memperjelas terhadap pertanyaan dianggap kurang oleh responden. Di samping itu tehnik ini juga mengetahui secara lebih mendetail beberapa alasan responden memberikan penilaian tertentu terhadap pertanyaan yang diajukan.

b. Kuesioner

Teknik dalam pengumpulan data yang digunakan dalam penelitian ini dengan cara menyebarkan kuesioner kepada para responden. Responden diminta untuk menanggapi dengan cara memberikan sikapnya terhadap variabel yang ada dengan menggunakan skala penilaian model likert demgan rentangan 1 sampai 5 untuk mengindikasikan jawaban sangat tidak setuju.

Definisi Operasional Dan Identitifikasi Variabel

Pada penelitian ini terdapat dua variabel yaitu, Variabel Bebas dan Variabel Terikat dengan definisi masing-masing variabel tersebut sebagai berikut:

1. Variabel Bebas dengan simbol $X$,yang terdiri dari empat variabel adalah sebagai berikut :

a. Produk (product)
Produk (product) dengan simbol $\mathrm{X}_{1}$, merupakan variabel bebas dengan definisi operasional yaitu semua jenis air minum dalam kemasan "HK" Di Desa Cenlecen Kecamatan Pakong Kabupaten Pamekasan dengan indikator:

1) Jenis air minum $H K$ sesuai dengan keinginan konsumen

2) Ukuran kemasan air minum HK yang ditawarkan kepada konsumen

3) Kualitas air minum HK yang dikonsumsi oleh konsumen

4) Kepuasan konsumen membeli produk air minum $\mathrm{HK}$

b. Harga (price)

Harga (price) dengan simbol $\mathrm{X}_{2}$, merupakan variabel bebas yang akan diukurdengan penilaian konsumen terhadap harga produk air minum dalam kemasan "HK"Di

Desa

CenlecenKecamatan Pakong Kabupaten Pamekasan dengan indikator :

5) Harga air minum HK sangat terjangkau

6) Variasi harga air minum HK

7) Proses pembelian air minum HK secara kontan

8) Perbandingan harga air minum HK dengan merek lainnya

Promosi (Promotion)

Promosi (Promotion) dengan simbol $X_{3}$ merupakan variabel bebas yaitu akan di ukur dengan minat konsumen terhadap promosi produk air minum kemasan "HK" Di Desa Cenlecen Kecamatan Pakong Kabupaten Pamekasan dengan indikator:

9) Tentang promosi yang di lakukan oleh HK Di Desa Cenlecen

10) Kepercayaan konsumen pada promosi yang disampaikan kepada konsumen

11) Bentuk promosi yang dapat menarik konsumen untuk membeli 
12) Perlu adanya promosi besarbesaran yang dilakukan $\mathrm{HK}$ Di Desa Cenlecen

Tempat (Place)

Tempat (Place) dengan simbol $\mathrm{X}_{4}$ merupakan lokasi atau tempat konsumen untuk dapat membeli air minum kemasan "HK" Di Desa Cenlencen Kecamatan Pakong Kabupaten Pamekasan dengan indikator :

13) Tempat usaha yang digunakan setrategis

14) Tempat usaha mudah dijangkau oleh masyarakat

15) Manfaat tempat usaha pada masyarakat sekitar

16) Suwasana tempat untuk melayani konsumennya

2. Variabel terikat dengan simbol Y,dalam hal ini adalah keputusan konsumen dalam memilih air minum dalam kemasan "HK"Di Desa Cenlecen Kecamatan Pakong Kabupaten Pamekasan dengan indikator :

17) Keinginan masyarakat membeli air minum HK

18) Informasi terhadap air minum HK yang disampaikan oleh masyarakat

19) Kesan atau tanggapan konsumen membeli air minum $\mathrm{HK}$

20) Keputusan membeli air minum $\mathrm{HK}$

21) Perbandingan air minum $H K$ dengan merek lainnya

\subsection{Pengujian Instrumen Data}

\subsubsection{Uji Validitas}

Teknik korelasi untuk melakukan validitas item, sampai sekarang merupakan teknik yang paling banyak digunakan.Item yang mempunyai korelasi positif dengan kriterium (skor total) serta korelasinya yang tinggi, menunjukkan bahwa item tersebut mempunyai validitas yang tinggi pula. Biasanya syarat minimum untuk dianggap memenuhi syarat adalah kalau $r=0,3$

\subsection{Uji Reliabilitas}

Menurut pendapat Sugiyono (2002:24) adalah :

Pengujian reliabilitas adalah sebagai berikut:"dilakukan dengan internal konsistensi dengan teknik belah dua atau split hal yang dianalisis dengan rumus sperman brown. Untuk keperluan itu maka butir-butir instrumen dibelah menjadi dua kelompok, yaitu instrumen ganjil dan kelompok genap.

\section{Teknik Analisis Data}

Pada penelitian ini terdapat dua macam analisis, yaitu analisis kualitatif dan analisi kuantitatif sebagai berikut :

\section{a. Analisis kualitatif}

Analisis kualitatif dimaksud untuk memberikan gambaran tentang objek yang diteliti, analisis ini akan mendeskripsikan jawaban responden pada skala likert, dengsan batasan pengukuran sebagai berikut :
1. Sangat baik
$=4,51 \mathrm{~s} / \mathrm{d}$
5,00
2. Baik 4,50
$=3,51 \mathrm{~s} / \mathrm{d}$
3. Cukup
$=2,51 \mathrm{~s} / \mathrm{d}$ 3,50
4. Tidak baik 2,50$$
=1,51 \mathrm{~s} / \mathrm{d}
$$
5. Sangat tidak baik $=1,00 \mathrm{~s} / \mathrm{d} 1,5$

\section{b. Analisis kuantitatif}

Analisis ini dimaksudkan untuk memberikan gambaran tentang kondisi objek yang diteliti berdasarkan perhitunag statistik. Adapun analisa yang digunakan pada penelitian ini adalah mengacu pada perusahaan regresi berganda 
menurut pndapat Sugiyono (2000:243) adalah sebagai berikut: $\mathbf{Y}=\mathbf{a}+\mathrm{b}_{1} \mathbf{X}_{1}+\mathrm{b}_{2} \mathbf{X}_{2}+\mathrm{b}_{3} \mathrm{X}_{3}+\mathrm{b}_{4} \mathrm{X}_{4} \ldots \mathrm{B}_{\mathrm{a}} \mathrm{X}_{\mathrm{a}}$ Dimana :

$\mathrm{Y}=$ variabel terikat yang ditentukan oleh besarnya variabel $X$

$X=$ variabel bebas yang menentukan besarnya nilai $Y$

$\mathrm{a}=$ nilai konstanta

$b=$ koefisien regresi antara variabel $X$ terhadap $Y$

Dengan demikian regresi yang digunakan pada penelitian ini adalah sebagai berikut :

$$
Y=a+b_{1} X_{1}+b_{2} X_{2}+b_{3} X_{3}+b_{4} X_{4}+e
$$

Dimana :

$Y$ : Kriterium atau variabel terikat (keputusan konsumen)

$\mathrm{X}_{1}$ : faktor produk

$\mathrm{X}_{2}$ : faktor harga

$\mathrm{X}_{3}$ : faktor promosi

$\mathrm{X}_{4}$ : faktor tempat

$b_{1}$ : koefisien regresi faktor produk

$b_{2}$ : koefisien regresi faktor harga

$\mathrm{b}_{3}$ : koefisien regresi faktor promosi

$\mathrm{b}_{4}$ : koefisien regresi faktor tempat

a : bilangan konstanta

e : error atau sisa

Dari hasil persamaan regresi tersebut dapat diketahui pengaruh besarnya hubungan antara variabel bebas secara bersama-sama terhadap variabel terikatnya. Untuk menghitung besarnya keeratan hubungan antara variabel bebas dengan variabel terikat, maka perlu mencari besarnya nilai koefisien korelasinya " $r$ ".

\section{HASIL PENELITIAN DAN PEMBAHASAN}

\subsection{Hasil Uji Validitas}

Suatu data dinyatakan valid apabila koefisien korelasi $r>0,3$ untuk uji validitas dalam penelitian ini sebagai berikut:

a. Faktor Produk :

1. Jenis air minum $\mathrm{HK}$ sesuai keinginan $=0,559>0,3$ (valid)
2. Ukuran kemasan air minum $\mathrm{HK}=0,571>0,3$ (valid)

3. Kualitas air minum $\mathrm{HK}=$ $0,509>0,3$ (valid)

4. Apakah puas setelah membeli air minum $\mathrm{HK}=$ $0,437>0,3$ (valid)

b. Faktor Harga

5. Harga terjangkau oleh masyarakat $=0,792>0,3$ (valid)

6. Variasi harga yang ditawarkan pada masyarakat $=0,445>0,3$ (valid)

7. Proses pembelian secara kontan $=0,376>0,3$ (valid)

8. Perbandingan harga dengan merek lainnya = $0,522>0,3$ (valid)

c. Faktor Promosi

9. Promosi yang dilakukan perusahaan $\mathrm{HK}=0,398>$ 0,3 (valid)

10. Bentuk promosi yang dipercaya perusahaan HK $=0,695>0,3$ (valid)

11. Bentuk promosi yang menarik konsumen = $0,656>0,3$ (valid)

12. Perlu adanya promosi besar-besaran $=0,684>$ 0,3 (valid)

d. Faktor Tempat

13. Tempat usaha yang strategis $=0,600>0,3$ (valid)

14. Tempat usaha mudah dijangkau masyarkat = $0,637>0,3$ (valid)

15. Tempat usaha bermanfaat bagi masyarakat sekitar $=$ $0,394>0,3$ (valid)

16. Suasana tempat melayani konsumen $=0,755>0,3$ (valid)

e. Faktor Keputusan Konsumen 
17. Keinginan masyarakat membeli air minum $\mathrm{HK}=$ $0,656>0,3$ (valid)

18. Informasi tentang air minum $\mathrm{HK}=0,800>0,3$ (valid)

19. Kesan / tanggapan yang di rasakan $=0,522>0,3$ (valid)

20. Keputusan tempat dengan membeli air minum $\mathrm{HK}=$ $0,473>0,3$ (valid)

21. Perbandingan air minum HKdengan merek lain = $0,800>0,3$ (valid)

Secara nominasi dapat di susun data yang valid, sebagai berikut :

\subsection{Hasil Uji Reabilitas}

Pada data SPSS 21dapat diketahui hasil $\mathbf{r}$ hitung dari variabel $X=0,783$ dan $r$ hitungdari $\mathrm{Y}=$ 0,785 makadenganmembandingkan nilai $\mathbf{r}$ tabel $0,05=0,254$ ternyata $r$ hitung $>$ dari pada $r$ tabel. Maka instrument data pada penelitian ini baik variabel $X$ dan $Y$ adalah Reabel.

\subsubsection{Hasil Persamaan Regresi Linier Berganda \\ Pada sumber data dari SPSS}

21dapat diketahui hasil persamaan linier regresi berganda adalah sebagai berikut :

$\mathbf{Y}=\mathbf{a}+\mathbf{b}_{1} \mathbf{X}_{1}+\mathbf{b}_{2} \mathbf{X}_{2}+\mathbf{b}_{3} \mathbf{X}_{3}+\mathbf{b}_{4} \mathbf{X}_{4}+E$

a. Konstan $=1,575$

$b_{1}=$ Koefisien korelasi faktor produk $=0,125$

$\mathrm{b}_{2}=$ Koefisien korelasi faktor

harga $=0,190$

$\mathrm{b}_{3}=$ Koefisien korelasi faktor promosi $=0,573$ (Faktor Dominan )

$\mathrm{b}_{4}=$ Koefisien korelasi faktor tempat $=0,099$
Maka persamaan regresinya adalah sebagai berikut :

$Y=1,575+0,125 X_{1}+0,190 X_{2}+$ $0,573 X_{3}+0,099 X_{4}$

Dari persamaan linier regresi berganda tersebutdapat diartikan sebagai berikut :

\section{a) Konstanta ( $\alpha$ )}

Jika semua variable bebas memiliki nilai nol (0) maka, nilai variable terikat $(\beta)$ sebesar 1,575

b) $\mathbf{0 , 1 2 5} X_{1}$ (Faktor Produk)

Artinya : jika faktor produk dapat di tingkatkan sebesar satu satuan produk yang ada pada saat ini ; maka ada konstribusi positif / bertahan faktor mempengaruhi keputusan konsumen untuk memilih air minum kemasan HK Di Desa Cenlecen Kecamatan Pakong Kabupaten Pamekasan, sebesar $12,50 \%$

\section{c) $0,190 \mathrm{X}_{2}$ (Faktor Harga)}

Artinya : jika faktor hargadapat di tingkatkan sebesar satu satuan harga yang ada pada saat ini ; maka ada konstribusi positif / bertahan faktor mempengaruhi keputusan konsumen untuk memilih air minum kemasan HK Di Desa Cenlecen Kecamatan Pakong Kabupaten Pamekasan, sebesar $19,00 \%$

\section{d) $0,573 \quad X_{3} \quad$ (Faktor Promosi/ Dominan)}

Artinya : jika faktor promosidapat di tingkatkan sebesar satu satuan promosi yang ada pada saat ini ; maka ada konstribusi positif / bertahan faktor mempengaruhi keputusan konsumen untuk memilih air minum kemasan HK Di Desa Cenlecen Kecamatan Pakong Kabupaten Pamekasan, sebesar $57,30 \%$

\section{e) 0,099 $\mathrm{X}_{4}$ (Faktor Tempat)}

Artinya : jika faktor tempatdapat di tingkatkan sebesar satu satuan tempat yang ada pada saat ini ; 
maka ada konstribusi positif / bertahan faktor mempengaruhi keputusan konsumen untuk memilih air minum kemasan HK Di Desa Cenlecen Kecamatan Pakong Kabupaten Pamekasan, sebesar $0,99 \%$

\subsection{PEMBAHASAN}

\subsubsection{Analisa Kualitatif}

Untuk faktor $X 1$, responden yang menjawab sangat baik 19 orang atau $31,7 \%$, yang menjawab baik 18 orang atau $30,0 \%$, dan yang menjawab cukup baik 15 orang atau $25,0 \%$, dan yang menjawab tidak baik 8 orang atau 13,3\%, sedangkan yang menjawab sangat tidak baik tidak ada atau $0 \%$.

Untuk faktor X1.2 responden menjawab sangat baik 20 orang atau $33,3 \%$, yang menjawab baik 14 orang atau $23,3 \%$, dan yang menjawab cukup baik 9 orang atau $15,0 \%$, dan yang menjawab tidak baik 13 orang atau $21,7 \%$, sedangkan yang menjawab sangat tidak baik sebanyak 4 orang atau $6,7 \%$.

Untuk faktor X1.3 responden menjawab sangat baik 18 orang atau $30,0 \%$, yang menjawab baik 20 orang atau 33,3\%, dan yang menjawab cukup baik 14 orang atau $23,3 \%$, dan yang menjawab tidak baik 8 orang atau $13,3 \%$, sedangkan yang menjawab sangat tidak baik tidak ada atau $0 \%$.

Untuk faktor X1.4 responden menjawab sangat baik 25 orang atau $41,7 \%$, yang menjawab baik 24 orang atau $40,0 \%$, dan yang menjawab cukup baik 6 orang atau $10,0 \%$, dan yang menjawab tidak baik 5 orang atau $8,3 \%$, sedangkan yang menjawab sangat tidak baik tidak ada atau $0 \%$.

Dari beberapa faktor untuk variabel produk yang di dapat mean 15,30 ini dapat diinterprestasikan bahwasanya produk air minum HK tergolong baik, hal ini perlu dipertahankan untuk masa-masa yang akan datang.

Berdasarkan tabel untuk faktor $\mathrm{X} 2$, responden yang menjawab sangat baik 8 orang atau 13,3\%, yang menjawab baik 22 orang atau $36,7 \%$, dan yang menjawab cukup baik 21 orang atau $35,0 \%$, dan yang menjawab tidak baik 6 orang atau $10,0 \%$, sedangkan yang menjawab sangat tidak baik 3 orang atau 5,0\%.

Untuk faktor X2.2 responden menjawab sangat baik 31 orang atau $51,7 \%$, yang menjawab baik 23 orang atau $38,3 \%$, dan yang menjawab cukup baik 4 orang atau $6,7 \%$, dan yang menjawab tidak baik 2 orang atau $3,3 \%$, sedangkan yang menjawab sangat tidak baik tidak ada atau $0 \%$.

Untuk faktor X2.3 responden menjawab sangat baik 11 orang atau $18,3 \%$, yang menjawab baik 22 orang atau $36,7 \%$, dan yang menjawab cukup baik 23 orang atau $38,3 \%$, dan yang menjawab tidak baik tidak ada atau $0 \%$, sedangkan yang menjawab sangat tidak baik 4 atau $6,7 \%$.

Untuk faktor X2.4 responden menjawab sangat baik 14 orang atau $23,3 \%$, yang menjawab baik 30 orang atau 50,0\%, dan yang menjawab cukup baik 2 orang atau $3,3 \%$, dan yang menjawab tidak baik 11 orang atau $18,3 \%$, sedangkan yang menjawab sangat tidak baik 3 orang atau $5,0 \%$.

Dari beberapa faktor untuk variabel harga yang di dapat mean 15,10 ini dapat diinterprestasikan bahwasanya produk air minum HK tergolong baik, hal ini perlu dipertahankan untuk masa-masa yang akan datang.

Berdasarkan tabel untuk faktor X3, responden yang menjawab 
sangat baik 13 orang atau $21,7 \%$, yang menjawab baik 27 orang atau $45,0 \%$, dan yang menjawab cukup baik 13 orang atau $21,7 \%$, dan yang menjawab tidak baik 7 orang atau $11,7 \%$, sedangkan yang menjawab sangat tidak baik tidak ada atau $0 \%$.

Untuk faktor X3.2 responden menjawab sangat baik 25 orang atau $41,7 \%$, yang menjawab baik 24 orang atau 40,0\%, dan yang menjawab cukup baik 6 orang atau $10,0 \%$, dan yang menjawab tidak baik 5 orang atau $8,3 \%$, sedangkan yang menjawab sangat tidak baik tidak ada atau $0 \%$.

Untuk faktor X3.3 responden menjawab sangat baik 17 orang atau $28,3 \%$, yang menjawab baik 18 orang atau $28,7 \%$, dan yang menjawab cukup baik 20 orang atau $33,3 \%$, dan yang menjawab tidak baik 6 orang atau $10,0 \%$, sedangkan yang menjawab sangat tidak baik tidak ada atau $0 \%$.

Untuk faktor X3.4 responden menjawab sangat baik 27 orang atau $45,0 \%$, yang menjawab baik 12 orang atau $20,0 \%$, dan yang menjawab cukup baik 19orang atau $31,7 \%$, dan yang menjawab tidak baik 2 orang atau 3,3\%, sedangkan yang menjawab sangat tidak baik tidak ada atau $0 \%$.

Dari beberapa faktor untuk variabel promosi yang di dapat mean 15,73 ini dapat diinterprestasikan bahwasanya produk air minum HK tergolong baik, hal ini perlu dipertahankan untuk masa-masa yang akan datang.

Berdasarkan tabel untuk faktor $\mathrm{X} 4$, responden yang menjawab sangat baik 16 orang atau $26,7 \%$, yang menjawab baik 12 orang atau $20,0 \%$, dan yang menjawab cukup baik 28 orang atau $46,7 \%$, dan yang menjawab tidak baik 4 orang atau $6,7 \%$, sedangkan yang menjawab sangat tidak baik tidak ada atau $0 \%$.
Untuk faktor $\mathrm{X} 4.2$ responden menjawab sangat baik 23 orang atau $38,3 \%$, yang menjawab baik 22 orang atau $36,7 \%$, dan yang menjawab cukup baik 15 orang atau $25,0 \%$, dan yang menjawab tidak baik tidak ada atau $0 \%$, sedangkan yang menjawab sangat tidak baik tidak ada atau $0 \%$.

Untuk faktor X4.3 responden menjawab sangat baik 14 orang atau $23,3 \%$, yang menjawab baik 38 orang atau $63,3 \%$, dan yang menjawab cukup baik 8 orang atau $13,3 \%$, dan yang menjawab tidak baik tidak ada atau $0 \%$, sedangkan yang menjawab sangat tidak baik tidak ada atau $0 \%$.

Untuk faktor X4.4 responden menjawab sangat baik 31 orang atau $51,7 \%$, yang menjawab baik 15 orang atau $25,0 \%$, dan yang menjawab cukup baik 9 orang atau $15,0 \%$, dan yang menjawab tidak baik 2 orang atau 3,3\%, sedangkan yang menjawab sangat tidak baik 3 orang atau $5,0 \%$.

Dari beberapa faktor untuk variabel tempat yang di dapat mean 16,05 ini dapat diinterprestasikan bahwasanya produk air minum HK tergolong baik, hal ini perlu dipertahankan untuk masa-masa yang akan datang.

Berdasarkan tabel untuk faktor $\mathrm{Y} 1$, responden yang menjawab sangat baik 17 orang atau $28,3 \%$, yang menjawab baik 16 orang atau $26,7 \%$, dan yang menjawab cukup baik 27 orang atau $45,0 \%$, dan yang menjawab tidak baik tidak ada atau $0 \%$, sedangkan yang menjawab sangat tidak baik tidak ada atau $0 \%$.

Untuk faktor Y1.2 responden menjawab sangat baik 17 orang atau $28,3 \%$, yang menjawab baik 25 orang atau $41,7 \%$, dan yang menjawab cukup baik 18 orang atau $30,0 \%$, dan yang menjawab tidak baik tidak ada atau $0 \%$, sedangkan 
yang menjawab sangat tidak baik tidak ada atau $0 \%$.

Untuk faktor Y1.3 responden menjawab sangat baik 26 orang atau $43,3 \%$, yang menjawab baik 27 orang atau 45,0\%, dan yang menjawab cukup baik 7 orang atau $11,7 \%$, dan yang menjawab tidak baik tidak ada atau $0 \%$, sedangkan yang menjawab sangat tidak baik tidak ada atau $0 \%$.

Untuk faktor Y1.4 responden menjawab sangat baik 15 orang atau $25,0 \%$, yang menjawab baik 20 orang atau $3,33 \%$, dan yang menjawab cukup baik 25orang atau $41,7 \%$, dan yang menjawab tidak baik tidak ada atau 0\%, sedangkan yang menjawab sangat tidak baik tidak ada atau $0 \%$.

Untuk faktor Y1.5 responden menjawab sangat baik 17 orang atau $28,3 \%$, yang menjawab baik 25 orang atau $41,7 \%$, dan yang menjawab cukup baik 18 Orang atau $30,0 \%$, dan yang menjawab tidak baik tidak ada atau $0 \%$, sedangkan yang menjawab sangat tidak baik tidak ada atau $0 \%$.

Dari beberapa faktor untuk variabel keputusan konsumen yang di dapat mean 19,95 ini dapat diinterprestasikan bahwasanya produk air minum HK tergolong baik, hal ini perlu dipertahankan untuk masa-masa yang akan datang.

\subsubsection{Analisa Kuantitatif}

Dari hasil perhitungan persamaan linier regresi berganda dengan menggunakan program SPSS 21. Diperoleh persamaan regresinya sebagai berikut :

$$
\begin{gathered}
Y=1,575+0,125 X_{1}+ \\
0,190 X_{2}+0,573 X_{3}+0,099 X_{4}
\end{gathered}
$$

Secara kuantitatif dari hasil persamaan linier regresi berganda di atas dapat disimpulkan sebagai berikut : Bahwa yang dapat mempengaruhi keputusan konsumen untuk memilih air minum kemasan HK Di Desa Cenlecen Kecamatan Pakong Kabupaten Pamekasan ; sebesar 1,575. Secara Nominasi dapat disusun keempat faktor Marketing Mix tersebut adalah sebagai berikut :

\section{a) Konstanta ( $\alpha$ )}

Jika semua variable bebas memiliki nilai nol (0) maka, nilai variable terikat $(\beta)$ sebesar 1,575

\section{b) $0,125 X_{1}$ (Faktor Produk)}

Artinya : jika faktor produk dapat di tingkatkan sebesar satu satuan produk yang ada pada saat ini ; maka ada konstribusi positif / bertahan faktor mempengaruhi keputusan konsumen untuk memilih air minum kemasan HK Di Desa Cenlecen Kecamatan Pakong Kabupaten Pamekasan, sebesar $12,50 \%$

\section{c) $0,190 \mathrm{X}_{2}$ (Faktor Harga)}

Artinya : jika faktor hargadapat di tingkatkan sebesar satu satuan harga yang ada pada saat ini ; maka ada konstribusi positif / bertahan faktor mempengaruhi keputusan konsumen untuk memilih air minum kemasan HK Di Desa Cenlecen Kecamatan Pakong Kabupaten Pamekasan, sebesar 19,00\%

d) $0,573 \quad X_{3} \quad$ (Faktor Promosi / Dominan)

Artinya : jika faktor promosidapat di tingkatkan sebesar satu satuan promosi yang ada pada saat ini ; maka ada konstribusi positif / bertahan faktor mempengaruhi keputusan konsumen untuk memilih air minum kemasan HK Di Desa Cenlecen Kecamatan Pakong Kabupaten Pamekasan, sebesar $57,30 \%$

\section{e) $0,099 \mathrm{X}_{4}$ (Faktor Tempat)}

Artinya : jika faktor tempatdapat di tingkatkan sebesar satu satuan tempat yang ada pada saat ini ; maka ada konstribusi positif / 
bertahan faktor mempengaruhi keputusan konsumen untuk memilih air minum kemasan HK Di Desa Cenlecen Kecamatan Pakong Kabupaten Pamekasan, sebesar $0,99 \%$

\subsubsection{Analisa Korelasi}

Hasil perhitungan $R$ dan $R$ Square menggunakan bantuan program SPSS 21 for windows dan dari data yang telah di sajikan dimasukkan kedalam program SPSS 21 for windows. Hasil diperoleh berada di data sebagai berikut:

\section{Tabel 4.3.3}

Hasil Perhitungan R dan Square

Model Summary

\begin{tabular}{|l|l|r|r|l|}
\hline Model & $R$ & R Square & \multicolumn{1}{|c|}{$\begin{array}{c}\text { Adjusted } R \\
\text { Square }\end{array}$} & $\begin{array}{c}\text { Std. } \\
\text { Error of } \\
\text { the } \\
\text { Estimate }\end{array}$ \\
\hline 1 &, $770^{\mathrm{a}}$ &, 593 &, 563 &, 37090 \\
\hline
\end{tabular}

a. Predictors: (Constant), X4 (Tempat), X1 (Produk), X2 (Harga), X3 (Promosi)

\section{$\mathbf{R}=\mathbf{0 , 7 7 0}$}

Artinya ada hubungan pada tingkat Positif Sedang yakni : sebesar $77,00 \%$ antara faktor produk, harga, promosi dan faktor tempat secara bersama-sama terhadap faktor yang mempengaruhi keputusan konsumen untuk memilih air minum kemasan $\mathrm{HK}$ di desa cenlecen kecamatan pakong kabupaten pamekasan.

\section{$\mathrm{R}$ Square $=0,593$}

Artinya ; besarnya sumbangan / konstribusi dari faktor produk, harga, promosi dan faktor tempat secara bersama-sama sebesar 59,30 \%. Sehingga masih ada faktor lain, selain faktor tersebut di atas ; yang dapat mempengaruhi keputusan konsumen untuk memilih air minum kemasan $\mathrm{HK}$ di desa cenlecen kecamatan pakong kabupaten pamekasan. Yakni : sebesar (100\%$59,30 \%)=40,70 \%$, yang perlu di kaji oleh pihak perusahaan.

\subsection{Uji Hipotesis}

\section{a. Hipotesis Pertama}

Diduga ada pengaruhfaktor marketing mix yang terdiri dari faktor produk, harga, promosi dan tempat secara bersamaan terhadap keputusan konsumen dalam memilih air minum kemasan "HK" Di Desa Cenlecen Kecamatan Pakong Kabupaten Pamekasan.

Dengan menggunakan tingkat kepercayaan $5 \%$ (Level of Signivicant) pada nilai $\mathrm{n}=60$ dengan 4 faktor variabel bebas ; maka di temukan angka $\mathrm{F}$ tabel = 2,53

Dari hasil perhitungan SPSS di temukan $F$ hitung $=20,041$ dengan Signifikan 0,000. Maka Uji F adalah sebagai berikut :

- Pada Uji-F

$F$ hitung $>F$ tabel atau

$20,041>2,53$ maka

$\mathrm{H}_{0}$ diterima dan $\mathrm{H}_{1}$ ditolak

Artinya ; bahwa dugaan

faktor produk, harga, promosi dan faktor tempat secara bersama-sama ada pengaruh terhadap keputusan konsumen memilih air minum kemasan $\mathrm{HK}$ di desa cenlecen kecamatan pakong kabupaten pamekasan ; adalah benar dapat diterima.

\section{b. Hipotesis Kedua}

Diduga faktor produk yang paling dominan terhadap keputusan konsumen dalam memilih air minum kemasan "HK" Di Desa Cenlecen Kecamatan Pakong Kabupaten Pamekasan.

Ternyata pada analisa secara kuantitatif terbukti pada faktor promosi paling dominan yakni ; memiliki nilai koefisien korelasi yang paling besar, sebesar $57,30 \%$.

Untuk Uji t nilai pada tabel dengan menggunakan derajat kebebasan (dk) pada tabel t dk 60 dengan uji dua pihak 0,05 ; maka ditemukan $t$ tabelnya sebesar 2,000. Sehingga dibandingkan nilai t hitung 
dan $\mathrm{t}$ tabel, pada masing-masing faktor sebagai berikut :

1) $\mathrm{Uji}_{1}=1,443$ (Faktor Produk)

$1,443<2,004$ yakni

t hitung $<$ t tabel

$\mathrm{H}_{0}$ diterima $\mathrm{H}_{1}$ ditolak

2) $\mathrm{Uji}_{2}=1,498$ (Faktor Harga) $1,498<2,004$

yakni

t hitung $<$ t tabel

$\mathrm{H}_{0}$ diterima $\mathrm{H}_{1}$ ditolak

3) $\mathrm{Uji} \mathrm{t}_{3}=5,208$ (Faktor Promosi)

$$
5,208>2,004
$$

yakni

t hitung $<$ t tabel

$\underline{\mathrm{H}}_{0}$ ditolak $\mathrm{H}_{1}$ diterima

(Signifikasi)

4) Uji t $_{4}=0,785$ (Faktor Tempat)

yakni

$0,785<2,004$

t hitung $<\mathrm{t}$ tabel

$\mathrm{H}_{0}$ diterima $\mathrm{H}_{1}$ ditolak

Dari hasil faktor promosi yang paling dominan : dan mempunyai pengaruh yang berarti / bermakna terhadap keputusan konsumen memilih air minum $\mathrm{HK}$ di desa cenlecen kecamatan pakong kabupaten pamekasan.

Sedangkan faktor produk, harga dan tempat tidak mempunyai pengaruh yang berarti / bermaknaterhadap keputusan konsumen memilih air minum kemasan $\mathrm{HK}$ di desa cenlecen kecamatan pakong kabupaten pamekasan.

\section{KESIMPULAN DAN SARAN}

\subsection{Kesimpulan}

a. Pada Uji Validitas sebanyak 21 Item semuanya valid.

b. Pada Uji Reabilitas dengan uji $r$ tabel dibandingkan dengan $r$ hitung dinyatakan reliable.

c. Dengan menggunakan sampel sebanyak 60 responden Makafaktor produk, harga, promosi dan tempat secara bersamasama ada pengaruh terhadap keputusan konsumen memilih air kemasan $\mathrm{HK}$ di desa cenlecen kecamatan pakong kabupaten pamesakan, Dapat di terima.

d. Faktor yang paling dominan berpengaruh adalah variable promosi yang dapat memberikan konstribusi yang paling besar terhadap keputusan konsumen.

e. Koefisien korelasi pada penelitian ini menunjukkan ada hubungan Positifantara faktor produk, harga, promosi dan faktor tempat terhadap keputusan konsumen.

\subsection{Saran-Saran}

a. Adanya nilai koefisien positif yang sangat besar yang mempunyai arti bahwa tanpa dipengaruhi oleh faktor marketing mixkonsumen yang sudah melampauwi batas yang Optimal. Maka perlu pembenahan kembali tentang marketing mix yang dilakukan pada usaha air minum HK di daesa cenlecen.

b. Mengingat hanya faktor promosi yang mempunyai pengaruh yang berarti / bermakna terhadap keputusan konsumen memilih air minum $\mathrm{HK}$ di desa cenlecen kecamatan pakong kabupaten pamekasan. Maka perlu ditinjau kembali pada faktor produk, harga, dan faktor tempat oleh pihak Manajemen Perusahaan.

c. Tidak kalah pentingnya juga pelayanan yang memuaskan dan ramah kepada pelanggan yang memilih air 
minum kemasan $\mathrm{HK}$, sangat menentukan bagi kelangsungan perusahaan.

d. Masih adanya faktor lain selain keempat faktor Marketing Mix yang relatif sangat besar yaitu ; 40,70\%. Maka perlu adanya penelitian lebih lanjut terhadap usaha pada air minum kemasan HK.

\section{DAFTAR PUSTAKA}

Arikonto Suharsimin, 2005, Manajemen Penelitian, edisirevisi, Jakarta : Penerbit PT Rineka Cipta

Darmawan, Didit, 2009, Dasar-Dasar Pemasaran. PT Metromedia Management, Surabaya

Malhotra, Naresh K. 2005, Marketing Research. New Jersey : Pearson Prentice Hall.

Nawang Prasti, Galuh. 2003, Analisis Pengaruh Persepsi Calon Konsumen Atas Bauran Promosi Terhadap Keputusan Menjadi Siswa English First Bukit MasSurabaya. UNAIR

Philip Kotler, 2002, Manajemen Pemasaran, PT. Prenhallindo, Jakarta

Philip Kotler, 2007, Manajemen Pemasaran. Edisi Kesebelas. terjemahan Darmawan PT Indeks, Jakarta.

Purbadi, Budi. 2002, Riset Pemasaran ; Penerbit PT Grasindo. Jakarta

Sugiyono. 2005, Metode Penelitian Bisnis, CV. Alfabeta. Bandung

Swasta dan Handoko, 2000, Manajemen Pemasaran Analisa Perilaku Konsumen. Edisi pertama, Yogyakarta. BPFE Yogyakarta.

Tjiptono, Fandy. 1997. Strategis Pemasaran. Edisi kedua. Ceatakan Pertama Penerbit Andi Offset, Yogyakarta.
Viera Walter E. 2002, Dasar-Dasar Pemasaran. Edisi kedua. terjemahan Angipora, Marius. PT Raja Grafindo Persada, Jakarta. 